\title{
Influence of tubificid worms on nutrient fluxes across water-sediment interface in fish farm settling ponds
}

\author{
J. Puigagut ${ }^{(3), \star}$, F. Chazarenc ${ }^{(2)}$, Y. Comeau ${ }^{(1)}$
}

Received July 9, 2013

Revised January 15, 2014

Accepted February 21, 2014

Key-words:
tubificids,
phosphorus,
ammonia,
nitrate,
fish farming,
settling ponds

\section{ABSTRACT}

The influence of tubificid worms on nutrient translocation from water to fish farm sediments accumulating in settling ponds was addressed under laboratory conditions. Small microcosms of $0.5 \mathrm{~L}$ were filled up with $35 \mathrm{~g}$ of sludge from a fish farm settling pond and $0.15 \mathrm{~L}$ of filtered settling pond water. The experimental set up consisted of one control line (no worms added), a second experimental line with $1 \mathrm{mg}$ of tubificid worms $\cdot \mathrm{g}^{-1}$ fresh sediment (550 individuals $\cdot \mathrm{m}^{-2}$ ) and a third experimental line with $40 \mathrm{mg}$ of tubificid worms $\cdot \mathrm{g}^{-1}$ fresh sediment $\left(22000\right.$ individuals $\left.\cdot \mathrm{m}^{-2}\right)$. Nutrients translocation was determined by monitoring overlaying water concentration of ammonia, nitrate and phosphate for ten days. Results showed that abundances of 550 individuals $\mathrm{m}^{-2}$ had no significant influence on the fluxes of nutrients here considered. However, the influence of higher abundances of tubificids ( 22000 individuals $\cdot \mathrm{m}^{-2}$ ) was of significant extent on the translocation of nitrate and phosphate. Accordingly, bioturbation of tubificids caused $55 \%$ lower nitrate uptake by the sediment when compared to control conditions. Phosphorus released by the sediments of the control condition was ca. $90 \%$ higher than that recorded under abundances of tubificids (22000 individuals $\cdot \mathrm{m}^{-2}$ ). Results obtained allowed us to estimate that fish farm settling ponds highly colonized by tubificid worms $\left(22000\right.$ individuals $\left.\mathrm{m}^{-2}\right)$ may contribute to decrease phosphorus discharge (in terms of soluble phosphorus) in ca. $5 \mathrm{~g}$ of P.ton ${ }^{-1}$ of fish produced.

\section{RÉSUMÉ}

L'influence des tubificidés sur les flux de nutriments à travers l'interface eau-sédiment dans les bassins de décantation d'une ferme aquacole

Mots-clés : tubificidés, phosphore, ammoniac, nitrate,

\begin{abstract}
L'influence des tubificidés sur le transfert des éléments nutritifs de l'eau aux sédiments de pisciculture qui s'accumulent dans les bassins de décantation a été abordée dans des conditions de laboratoire. De petits microcosmes de 0,5 L ont été remplis avec $35 \mathrm{~g}$ de boues provenant de sédiments d'une ferme aquacole et $0,15 \mathrm{~L}$ d'eau filtrée du décanteur. Le dispositif expérimental a consisté en une ligne de contrôle (pas de vers ajoutés), une deuxième ligne expérimentale avec $1 \mathrm{mg}$ de tubificidés. $\mathrm{g}^{-1}$ de sédiments frais (550 individus. $\mathrm{m}^{-2}$ ) et une
\end{abstract}

(1) Department of Civil, Geological and Mining Engineering, École Polytechnique of Montreal, 2500, chemin de Polytechnique, Montreal, (Quebec) Canada H3T 1J4

(2) Ecole des Mines de Nantes. 4, rue Alfred Kastler, La Chantrerie, B.P. 20722, F-44307 Nantes Cedex 3, France

(3) GEMMA. Department of Hydraulic, Maritime and Environmental Engineering. Universitat Politècnica de Catalunya. BarcelonaTech. c/ Jordi Girona 1-3. Building D1, 08034 Barcelona, Spain

* Corresponding author: jaume.puigagut@upc.edu 
pisciculture, bassins de décantation troisième ligne expérimentale avec $40 \mathrm{mg}$ de tubificidés $\mathrm{g}^{-1}$ de sédiments frais (22000 individus $\mathrm{m}^{-2}$ ). Le transfert des nutriments a été déterminé en suivant la concentration d'ammoniac, de nitrate et de phosphate de l'eau à l'interface avec le sédiment pendant dix jours. Les résultats ont montré que l'abondance de 550 individus. $\mathrm{m}^{-2}$ n'a eu aucune influence significative sur les flux de nutriments considérés ici. Par contre, l'influence de la plus grande abondance de tubificidés (22000 individus $\mathrm{m}^{-2}$ ) était significative pour les flux de nitrate et phosphate. Ainsi, la bioturbation par les tubificidés entraîne une absorption du nitrate par les sédiments inférieure de 55 \% par rapport aux conditions de contrôle. Le phosphore libéré par les sédiments dans les conditions de contrôle est environ $90 \%$ supérieur à la quantité libérée sous une forte abondance de tubificidés (22000 individus $\mathrm{m}^{-2}$ ). Les résultats obtenus nous ont permis d'estimer que les bassins de décantation de la ferme aquacole très colonisés par les tubificidés peuvent contribuer à diminuer les rejets de phosphore (en termes de phosphore soluble) d'environ $5 \mathrm{~g}$ de $\mathrm{P}$ par tonne de poissons produits.

\section{INTRODUCTION}

Fish farm activities are recognized as a potential source for pollution (Boaventura, 1997; True 2004) which results in significant changes in the physical, chemical and biological characteristics of the receiving streams (Delgado et al., 1999; Lampadariou et al., 2008). Nitrogen (N) and phosphorus $(P)$ are the two main pollutants related to aquaculture (Reddy et al., 1999). Phosphorus discharge by fish farming activity is of special concern since excessive $P$ to receiving waters leads to water quality degradation through eutrophication (Reddy et al., 1999; True, 2004).

Nutrients and organic matter at the effluent of fish farming facilities come either from fish excreta or from the decomposition or resuspension of fish farming sludge (mainly faeces, uneaten food and carcass debris). Furthermore, since sludge generated from fish production is a key issue related to the contamination within the aquaculture domain, management strategies and/or disposal of this residue have been widely addressed in current literature (Cripps and Bergheim, 2000 and references therein). Accordingly, microscreens, filter beds, Cornell-type circular tanks and settling tanks are among most applied technologies for sludge management. However, for small production facilities (less than 25 tonnes of fish produced per year) such technologies are of difficult implementation since they are relatively expensive and labour intensive (Bergheim and Brinker, 2003). Therefore, for small production facilities, sludge extraction and disposal on settling ponds is the usual practice (Lefrançois et al., 2010). Accordingly, the sludge conveyed to the settling pond is usually removed once a year, which means that the sludge might be subjected for a long period not only to resuspension and/or hydrolysis by bacteria, but also to other biological activities such as bioturbation.

Bioturbation carried out by benthic organisms (such as chironomid laravaes or tubificid worms) is defined as the sediment processing by animals during burrowing, sediment ingestion/defecation, tube building and biodeposition (Reible et al., 1996). As a result of bioturbation the sediment particles and pore water is subjected to a vertical and horizontal movement that leads to the mixing of upper sediment surface (Robins et al., 1979; Robins, 1982).

Bioturbation induces changes on the bio-geo-chemistry at the water-sediment interface (changing even the physical structure of the sediment) via fluid advection, solute diffusion or sediment slumping (Aller, 1994; Navel et al., 2011; Nogaro et al., 2009). Moreover, benthic organisms may not only enhance bacterial activity (Krantzberg, 1985, and references therein) but also promote the downward transport of oxygen and other electron acceptors Overall, the effect of bioturbation on the bio-geo-chemical processes occurring at the water-sediment interface depends not only upon the physical and chemical characteristics of the sediment (Gerino et al., 2003; Mermillod-Blondin and Rosenberg, 2006; Nogaro et al., 2009) but also on the type of benthic organism (Matisoff et al., 1985; Zhang et al., 2010). Tubificid worms belong 
to the functional group of upward- conveyors (or conveyor-belt species) (François et al., 2002; Gerino et al., 2003). Tubificids ingest buried sediments few centimetres in depth and faeces are deposited on the surface. Tubificid worms, through their burrowing, feeding and respiration movements, have been described to enhance not only nutrients and organic matter release from sediments (Fukuhara and Sakamoto, 1987; Mermillod-Blondin et al., 2005) but also the bacterial activity (Banta et al., 1999; Heilskov and Holmer, 2001; Mermillod-Blondin et al., 2005; Navel et al., 2011; Van de Bund et al., 1994) and oxygen consumption (Lagauzère et al., 2009; Mermillod-Blondin et al., 2005).

Overall, bioturbation of bottom sediments at the sediment-water interface is currently gaining more attention in studies dealing with the functioning of aquatic ecosystems (Adámek and Maršálek, 2013). However, in the context of fish farming, the number of studies dealing with the contribution of tuficids to nutrients dynamics (especially phosphorus) is still scarce. Therefore, the objective of the present work was to determine (under laboratory conditions) the influence of natural assemblages of tubificid worms on nutrients translocation across the water-sediment interface of fish farm settling ponds. The potential contribution of bioturbation on minimizing the phosphorus discharged by fish farms settling ponds is also discussed.

\section{MATERIAL AND METHODS}

\section{> ASSESSING THE ABUNDANCE OF NATURAL ASSEMBLAGES OF TUBIFICIDS}

The surveyed settling pond (of $194 \mathrm{~m}^{3}$ of volume) was located in a typical fish farm in southeastern Quebec (Canada) devoted to the production of rainbow trout (Oncorhynchus mykiss). In order to determine not only de natural abundances of tubifcids worms in the field but also its vertical distribution, the settling pond was surveyed in two occasions prior to onset of laboratory experiments. To this aim, sediment samples from the settling pond were collected using a Eijkelkamp multisampler specifically set to take solid samples. The multisampler was equipped with a sampling column made of PMM (an acrylic high transparent plastic) of $1 \mathrm{~m}$ length by $40 \mathrm{~mm}$ diameter ending up with a sharp edge made out of stainless steel. The sampling device was introduced within the sediment and a core of $15 \mathrm{~cm}$ was taken (the height of the core extracted was approximately that of the height of sludge accumulated at the pond). This procedure was repeated in three different spots located at the middle and edges of the basin. A mixture of soil and sludge (faeces and uneaten food) was therefore collected when sampling. Tubificids distribution within the representative sediment core was determined in situ. Tubificids were mainly distributed within the first $2 \mathrm{~cm}$ of sediment layer, which is in accordance to that described by Nogaro and Mermillod-Blondin, 2009. For tubificids quantification, the sediment core was preserved in a cooler for transport until it was processed (within the same day) at the laboratory facilities. Tubificid worms (mainly belonging to the Tubifex genus) were counted and weighted following a similar procedure than that described by Devine and Vanni (2002). Briefly, a known volume of sediment was passed through a sieve (500 $\mu \mathrm{m}$ mesh) to remove most of the sediment particles. Afterwards, the number of worms per known volume of sludge was assessed by counting the tubificids under a dissecting microscoscope and expressed per unit of fresh weight of worm as explained below. The abundances of tubificids presented a patchy distribution with lower abundances (ca. $1 \mathrm{mg}$ of worms per gram of fresh sediment) at the centre of the pond (deeper zone $-1.5 \mathrm{~m}$ ) and higher abundances (ca. $40 \mathrm{mg}$ of worms per gram of fresh sediment) at the edge of the pond (shallower zone $-0.1 \mathrm{~m}$ ). The density of tubificids was expressed as per unit of surface by following this procedure in triplicate: 40 worms were carefully separated by hand from sediment samples (using laboratory tweezers) washed with bottled water (to removed debris and small sediment particles) and the excess of water removed by gentle application of cellulose laboratory paper. Once the worms were clean and dry they were weighted and the relationship between number of worms and wet weight determined. For the laboratory experiments a certain amount of tubificid worms (processed as previously described) were weighted and introduced within the experimental vessels to reach the desired experimental condition ( 1 and 
Table I

Physical and chemical characteristics of sediment and pond water used for the laboratory experiments. a pond water employed to re-fill after sampling.

\begin{tabular}{|c|c|c|}
\hline Parameter & Pond water ${ }^{2}$ & Sediment \\
\hline TP (mg.g ${ }^{-1}$ total solids) & - & $3.1 \pm 0.3$ \\
\hline TN (mg $\cdot g^{1}$ total solids) & - & $5.4 \pm 1.1$ \\
\hline TOC (mg $\cdot \mathrm{g}^{-1}$ total solids) & - & $56.15 \pm 2.3$ \\
\hline Humidity (\%) & - & $63.2 \pm 0.2$ \\
\hline Total solids (TS) (\%) & - & $36.8 \pm 0.2$ \\
\hline Total volatile solids (VS) (\%) & - & $3.7 \pm 0.07$ \\
\hline Tot-Fe (mg.g ${ }^{-1}$ total solids) & - & $4.8 \pm 1.1$ \\
\hline $\mathrm{PO}_{4}-\mathrm{P}\left(\mathrm{mg} \cdot \mathrm{L}^{-1}\right)$ & $0.08 \pm 0.05$ & - \\
\hline $\mathrm{NH}_{4}-\mathrm{N}\left(\mathrm{mg} \cdot \mathrm{L}^{-1}\right)$ & $0.65 \pm 0.1$ & - \\
\hline $\mathrm{NO}_{3}-\mathrm{N}\left(\mathrm{mg} \cdot \mathrm{L}^{-1}\right)$ & $2.3 \pm 0.2$ & - \\
\hline
\end{tabular}

$40 \mathrm{mg}$ of worms $\cdot \mathrm{g}^{-1}$ fresh sediment). The amount of worms expressed per unit of surface was then calculated according to the relation between fresh weight of worms and number of individuals and divided by the surface of the vessels employed.

\section{> WATER AND SEDIMENT EMPLOYED FOR LABORATORY EXPERIMENTS}

The water was collected at the exit of the settling pond (effluent pipe) Sediment samples (three sediment cores from the middle and three from edges of the pond) were mixed and treated as a composite sample representative of the whole pond. The sediment samples collected were kept in the freezer for one week to get rid of the natural assemblages of tubificids. The physical and chemical parameters of the water and sediment used are summarized in Table I.

\section{> EXPERIMENTAL SET-UP}

The experimental set-up consisted of six glass vessels of $0.5 \mathrm{~L}$ ( $33 \mathrm{~cm}$ high to $4.2 \mathrm{~cm}$ of radius) covered with and opaque material to which $35 \mathrm{gram}$ of sediment $\left(\rho=1.2 \mathrm{~g} \cdot \mathrm{mL}^{-1}\right)$ from the settling pond and $0.3 \mathrm{~L}$ of filtered (at $0.45 \mu \mathrm{m}$ ) pond water were added. Pond water was filtered to get rid of bacteria that may change the physical-chemical characteristics of the water used to compensate sample extraction for analyses. Experimental vessels were supplied with air bubbling by means of aquarium pumps. Air bubbling was carried out from the top of the vessels to avoid sediment re-suspension. Furthermore, the amount of sediment added to the vessels provided a sediment layer of $2 \mathrm{~cm}$ (which mimicked the original distribution along the depth in the surveyed settling pond - see Sect. 2.1) and the water height above the sediment was that of $20 \mathrm{~cm}$. Two of the vessels were left as controls (no worms added), two were used for the first experimental condition (low abundances of tubificids - $1 \mathrm{mg}$ worms per gram of fresh sediment - equivalent to 550 individuals $\cdot \mathrm{m}^{-2}$ ) and the two remaining were used for the second experimental condition (high abundances of tubificids $-40 \mathrm{mg}$ of worms per gram of fresh sediment - equivalent to 22000 individuals $\cdot \mathrm{m}^{-2}$ ). It is worth mentioning that natural assemblages of tubificid worms collected in the field were kept in the laboratory for one month before the on-set of experiments in order to acclimatise them.

\section{> EXPERIMENTAL PROCEDURE AND ANALYSES}

Sediment and filtered pond water were introduced in the experimental vessels fifteen days before the on-set of laboratory experiments (which was considered enough time to reach steady state conditions after sediment homogenization). Note that nutrient concentration in overlaying water was sampled twice (after 2 and 14 days before the introduction of tubificids) 
to check that initial conditions were the same for all the experimental lines before the on-set of experiments. After the introduction of the tubificids. Every two days (for 10 days) overlaying water samples of $0.15 \mathrm{~L}$ were extracted for chemical analyses and the volume replaced by carefully adding new filtered pond water. To this regard, no visual sediment re-suspension was observed during water extraction or re-filling. Water samples (either from sampled overlaying water or filtered pond water for re-filling) were analysed each sampling day for $\mathrm{PO}_{4}^{-3}-\mathrm{P}$, $\mathrm{NH}_{4}^{+}-\mathrm{N}$ and $\mathrm{NO}_{3}-\mathrm{N}$ according to Apha-Awwa-Wpcf (2001). Translocation of nutrients across the water-sediment interface were calculated by the difference in recorded concentrations between two consecutive sampling days and expressed per unit of sludge used as follows:

$$
\varphi_{n}=\frac{\left(C_{i} V_{b}+C_{p} V_{p}\right)-\left(C_{i+1} V\right)}{\Delta T S}
$$

where,

- $\varphi_{n}:$ is nutrients translocation (in mg nutrient.gTS ${ }^{-1}$ )

- $C_{i}$ : is the nutrient concentration of a sampling day $i$ (in $\mathrm{mg} \cdot \mathrm{L}^{-1}$ )

- $V_{b}$ : is the volume of overlaying water remaining after sampling (in $L$ ),

$-C_{p}$ : is the nutrient concentration of the pond water added for re-filling (in $\mathrm{mg} \cdot \mathrm{L}^{-1}$ )

- $V_{p}$ : is the volume of pond water used for refilling (in $L$ )

$-C_{i+1}$ : is the nutrient concentration of a following sampling day $i+1$ (in $\mathrm{mg} \cdot \mathrm{L}^{-1}$ )

- $V:$ is the total volume of the beaker (in $L$ )

- $S$ : is the mass of sludge in the beaker (in g of total solids - TS)

- $\Delta T$ : is the elapsed time between two sampling events (days).

Nutrients fluxes calculated from the above equation can be negative or positive. To this regard, positive fluxes indicate that there was a net transference of nutrients from overlaying water to sediment and negative fluxes indicated that there was net release of nutrients from sediment to overlaying water.

Results on nutrient translocation from overlaying water to sediment will be expressed per unit of total solids (TS) in order to discuss the potential effect of tubificid worms on nutrient translocation from overlaying water to sediment in the context of fish farming.

Furthermore, oxygen, $\mathrm{pH}$ and temperature were daily measured to ensure comparable conditions among experimental conditions $(\mathrm{pH}$ ranged between 7.5 and 8.0 temperature between 19.5 and $20.5{ }^{\circ} \mathrm{C}$ and oxygen concentration ranged from 5.5 to $6.5 \mathrm{mg} \cdot \mathrm{L}^{-1}$, regardless the experimental condition considered).

\section{> STATISTICAL ANALYSES}

Differences among treatment lines before the introduction of tubificids were analysed for each nutrient by performing ONE-way ANOVA with three levels (no worms; $1 \mathrm{mg}$ of worms and $40 \mathrm{mg}$ of worms). Differences among levels of the same factor were determined by means of a Tukey-test. Analyses were considered statistically significant at $p$ values below 0.05 .

Differences among time for each experimental condition considered in regards to quality parameters were determined by means of ONE-way repeated-measures ANOVA with three levels (no worms; $1 \mathrm{mg}$ of worms and $40 \mathrm{mg}$ of worms). Homogeneity of variances and normality of data were tested by performing a Levene test and a Kolmogorov-Smirnov test, respectively. All statistical analyses were performed using SPSS v.19. Differences among levels of the same factor were determined by means of a Tukey-test. Analyses were considered statistically significant at $p$ values below 0.05 .

\section{RESULTS}

\section{$>$ INITIAL CONDITIONS}

In order to ensure homogeneous conditions among treatment lines, water quality parameters were measured in overlaying water before the introduction of worms. Accordingly, Figure 1 


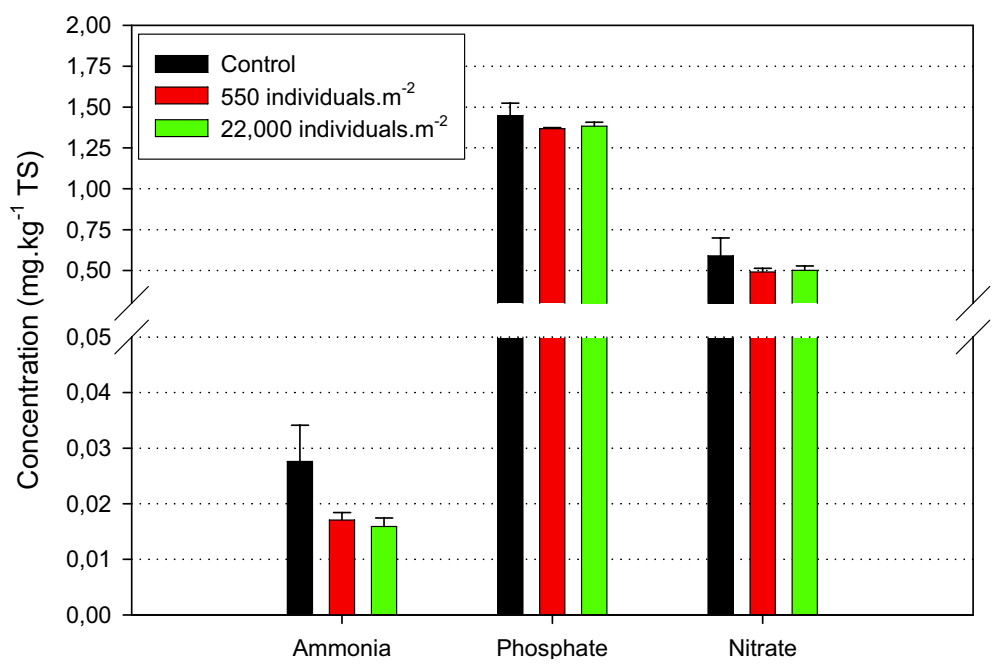

Figure 1

Concentrations of nutrients (in $\mathrm{mg} \cdot \mathrm{kg}^{-1} \mathrm{TS}$ ) for each experimental condition before the introduction of tubificid worms.

\section{Table II}

Cumulative uptake of ammonia from overlaying water to sediment for each experimental condition.

\begin{tabular}{|l|c|c|c|}
\hline \multirow{2}{*}{ Time (days) } & \multicolumn{3}{|c|}{ Experimental condition } \\
\cline { 2 - 4 } & Control & 550 individuals $\mathbf{m}^{-2}$ & 22000 individuals $\cdot \mathrm{m}^{-2}$ \\
\hline $\mathbf{2}$ & $10.1 \pm 0.1$ & $10.1 \pm 0.0$ & $9.9 \pm 0.0$ \\
\hline $\mathbf{4}$ & $19.8 \pm 0.0$ & $19.8 \pm 0.0$ & $19.4 \pm 0.3$ \\
\hline $\mathbf{6}$ & $24.1 \pm 0.1$ & $24 \pm 0.1$ & $23.9 \pm 0.2$ \\
\hline $\mathbf{8}$ & $31.2 \pm 0.1$ & $31.2 \pm 0.0$ & $31 \pm 0.2$ \\
\hline $\mathbf{1 0}$ & $32.5 \pm 0.1$ & $32.4 \pm 0.0$ & $32.3 \pm 0.2$ \\
\hline
\end{tabular}

Table III

Minimum, maximum and average values of nutrient fluxes from overlaying water to sediment (in $m g$ TS $\left.\cdot m^{-2} \cdot d a y^{-1}\right)$.

\begin{tabular}{|l|c|c|c|c|c|c|c|c|c|}
\hline & \multicolumn{3}{|c|}{ Phosphates $\left(\mathrm{PO}_{4}^{-3}-\mathrm{P}\right)$} & \multicolumn{3}{|c|}{ Ammonia $\left(\mathrm{NH}_{4}-\mathrm{N}\right)$} & \multicolumn{3}{|c|}{ Nitrates $\left(\mathrm{NO}_{3}-\mathrm{N}\right)$} \\
\hline & MIN & MAX & AVG & MIN & MAX & AVG & MIN & MAX & AVG \\
\hline Control & -9.7 & -3.2 & -7.1 & 0.9 & 7.1 & 4.6 & 9.5 & 17.4 & 13.6 \\
\hline $\mathbf{5 5 0}$ individuals $\cdot \mathbf{m}^{-\mathbf{2}}$ & -9.9 & -1.6 & -6.8 & 0.9 & 7.1 & 4.6 & 10.1 & 18.3 & 18.1 \\
\hline $\mathbf{2 2 0 0 0}$ individuals $\cdot \mathbf{m}^{-\mathbf{2}}$ & -7.5 & 4.6 & -0.6 & 0.9 & 7.0 & 4.5 & -2.6 & 12.7 & 6.3 \\
\hline
\end{tabular}

presents the concentration of nutrients in overlaying water after fourteen days of sediment and pond water introduction (acclimatizing phase). Note that nutrients concentration in overlaying water was not significantly different for any of the nutrients considered.

\section{$>$ AMMONIA}

According to our results ammonia was taken up by the sediment regardless the abundance of tubificids (Table II). More precisely, ammonia fluxes from water to sediment ranged from 0.9 to $7.1 \mathrm{mg} \mathrm{NH} \mathrm{NH}_{4}-\mathrm{N} \cdot \mathrm{m}^{-2}$. day ${ }^{-2}$, regardless the experimental condition considered (Table III).

\section{$>$ NITRATE}

Results obtained showed that nitrate concentration in overlaying water was significantly affected by the abundance of tubificid worms (Figure 2). More precisely, nitrate fluxes from 


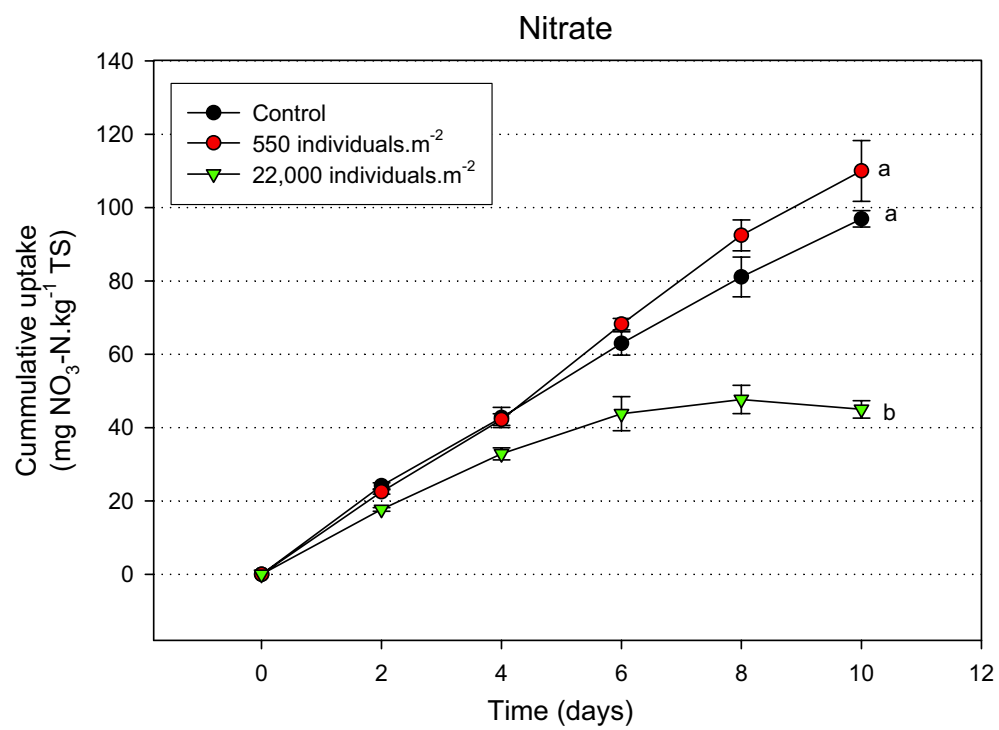

\section{Figure 2}

Cumulative translocation of nitrate from overlaying water to sediment for each experimental condition. Note: $a$ and $b$ are statistical groups of significance determined by a post-hoc test (Tukey test).

water to sediment ranged from 9.5 to $17.4 \mathrm{mg} \mathrm{NO}{ }_{3}-\mathrm{N} \cdot \mathrm{m}^{-2} \cdot$ day $^{-2}, 10.1$ to $18.3 \mathrm{mg} \mathrm{NO}_{3}$ $\mathrm{N} \cdot \mathrm{m}^{-2}$. day ${ }^{-2}$ and -2.6 to $12.7 \mathrm{mg} \mathrm{NO} \mathrm{N}_{3}-\mathrm{N} \cdot \mathrm{m}^{-2}$. day ${ }^{-2}$ to the control, 550 individuals $\cdot \mathrm{m}^{-2}$ and 22000 individuals $\cdot \mathrm{m}^{-2}$, respectively (Table III). In spite that nitrate was taken up by the sediment under any experimental condition tested, it was significantly lower under higher abundances of tubificids ( $45 \mathrm{mg}-\mathrm{NO}_{3} \mathrm{~N} \cdot \mathrm{kg}^{-1} \mathrm{TS}$ after ten days of experiment- Figure 2) than that of the control (97 mg NO $3-\mathrm{N} \cdot \mathrm{kg}^{-1} \mathrm{TS}$ after ten days of experiment - Figure 2). Overall, after ten days of experimentation the sediment under tubificid abundances of 22000 individuals $\cdot \mathrm{m}^{-2}$ showed $55 \%$ lower nitrate uptake than that of the control conditions (no worms present).

\section{> PHOSPHATE}

Phosphorus uptake by the sediment under tubificid abundances of 22000 individuals $\cdot \mathrm{m}^{-2}$ was significantly higher than that of the control or the sediment under tubificid abundances of 550 individuals $\mathrm{m}^{-2}$ (Figure 3). More precisely, phosphate fluxes from water to sediment ranged from -9.7 to $-3.2 \mathrm{mg} \mathrm{PO}_{4}^{-3}-\mathrm{P} \cdot \mathrm{m}^{-2}$. day ${ }^{-2},-9.9$ to $-1.6 \mathrm{mg} \mathrm{PO}_{4}^{-3}-\mathrm{P} \cdot \mathrm{m}^{-2} \cdot$ day $^{-2}$ and -7.6 to $4.6 \mathrm{mg} \mathrm{PO}-3-\mathrm{P} \cdot \mathrm{m}^{-2} \cdot$ day $^{-2}$ to the control, 550 individuals $\cdot \mathrm{m}^{-2}$ and 22000 individuals $\cdot \mathrm{m}^{-2}$, respectively (Table III). Moreover, the cumulative amount of phosphorus uptaken after ten days of experiment was that of $4.2 \mathrm{mg} \mathrm{PO}-3-\mathrm{P} \cdot \mathrm{kg}^{-1} \mathrm{TS}$ under high abundances of tubificids (Figure 3), whereas it was ca. $90 \%$ higher (-50 mg PO$\left.-3-\mathrm{P}_{4} \cdot \mathrm{kg}^{-1} \mathrm{TS}\right)$ (Figure 3) for the rest of experimental conditions.

\section{DISCUSSION}

\section{> NUTRIENT DYNAMICS ACROSS WATER-SEDIMENT INTERFACE}

It has been long known that tubificid worms increase the redox potential of surface sediments (Davis, 1974) that, in turn, may stimulate nitrification for a wide range of tubificid abundances (from 12000 to 27000 individuals. $\mathrm{m}^{-2}$ ) (Chatarpaul et al., 1980; Svensson et al., 2001). To this regard, authors believe that the absence of differences among experimental conditions (see Table II) might be explained by the fact that the oxygenation of the upper part of the sediment under control conditions (no worms) might have been enough to provide an oxic 


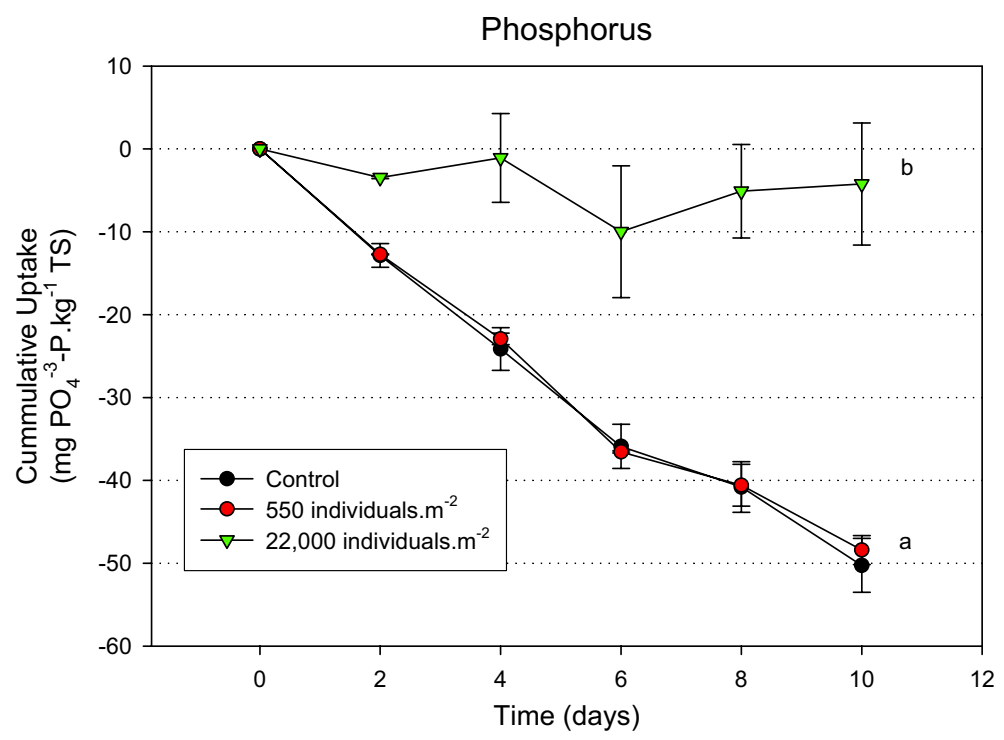

Figure 3

Cumulative translocation of phosphate from overlaying water to sediment for each experimental condition. Note: $a$ and $b$ are statistical groups of significance determined by a post-hoc test (Tukey test).

layer in which nitrification bacteria would have been able to oxidize either the low ammonia concentrations in overlaying water (ca. $0.65 \mathrm{mg} \mathrm{NH}_{4}-\mathrm{N} \cdot \mathrm{L}^{-1}$ - Table I) or those coming from the interstitial water. Accordingly, high ammonia removal carried out at the surface of the control conditions might have masked the effect of tubificids. This hypothesis is based on the visual appearance of the sediment surface of the control line (ca. the first $5 \mathrm{~mm}$ of the sediment layer) which was of light orange colour (probably due to ferric hydroxides under high redox conditions), whereas the rest of the sediment remained blackish (probably due to ferrous sulphide under low redox conditions) (Figure 4a).

Concerning nitrate dynamics across water-sediment interface, authors believe that sediment reworking carried out by tubificid abundances of 22000 individuals. $\mathrm{m}^{-2}$ (see Figure $4 \mathrm{~b}$ ) was enough to increase the oxygen transfer to the sediment when compared to control conditions (Figure 6a). As a consequence of higher oxygen concentrations within the sediment dentrification was significantly decreased. More precisely, nitrate fluxes were, in average, two times lower than that of the control line (Table III). Our results are in agreement to that previously described by Gilbert et al. (1995); these authors observed that denitrification was inhibited at the upper sediment layer (first $2 \mathrm{~cm}$ ) because of bioturbation increased the oxygen penetration into the sediment.

Cumulative phosphorus uptake for the control and the sediment under tubificid abundances of 550 individuals. $\mathrm{m}^{-2}$ was of similar extent than that described by Puigagut et al. (2011) working under similar conditions. Bioturbation caused by tubificid worms has been related to decrease phosphorus release from sediments (Andersen and Jensen, 1991; Davies et al., 1975; Lewandowski and Jupfer, 2005; Mortimer et al., 1999; Zhang et al., 2010; Heilskov and Holmer, 2001). Enhanced phosphorus retention by a sediment highly bioturbated is probably due to the effect of redox changing conditions imposed by tubificids. Accordingly, sediment reworking increases the transfer of electrons acceptors from overlaying water (such as oxygen) to deeper zones of the sediment (Andersson et al., 1988) which, in turn, may enhance the precipitation of phosphorus with iron hydroxides whenever iron is present (Davis et al., 1975; Lewandowski and Jupfer, 2005). The sediment here employed (Table I) cannot be considered as iron-rich sediment, but it has been reported that low total iron to total phosphorus molar ratio in sediments (which is precisely our case where Fe:P is ca. 3 - see calculation 3 in supplementary material) is associated to low conditions of phosphorus release (Phillips et al., 1994). Therefore, our results suggest that even under moderate concentrations of iron 

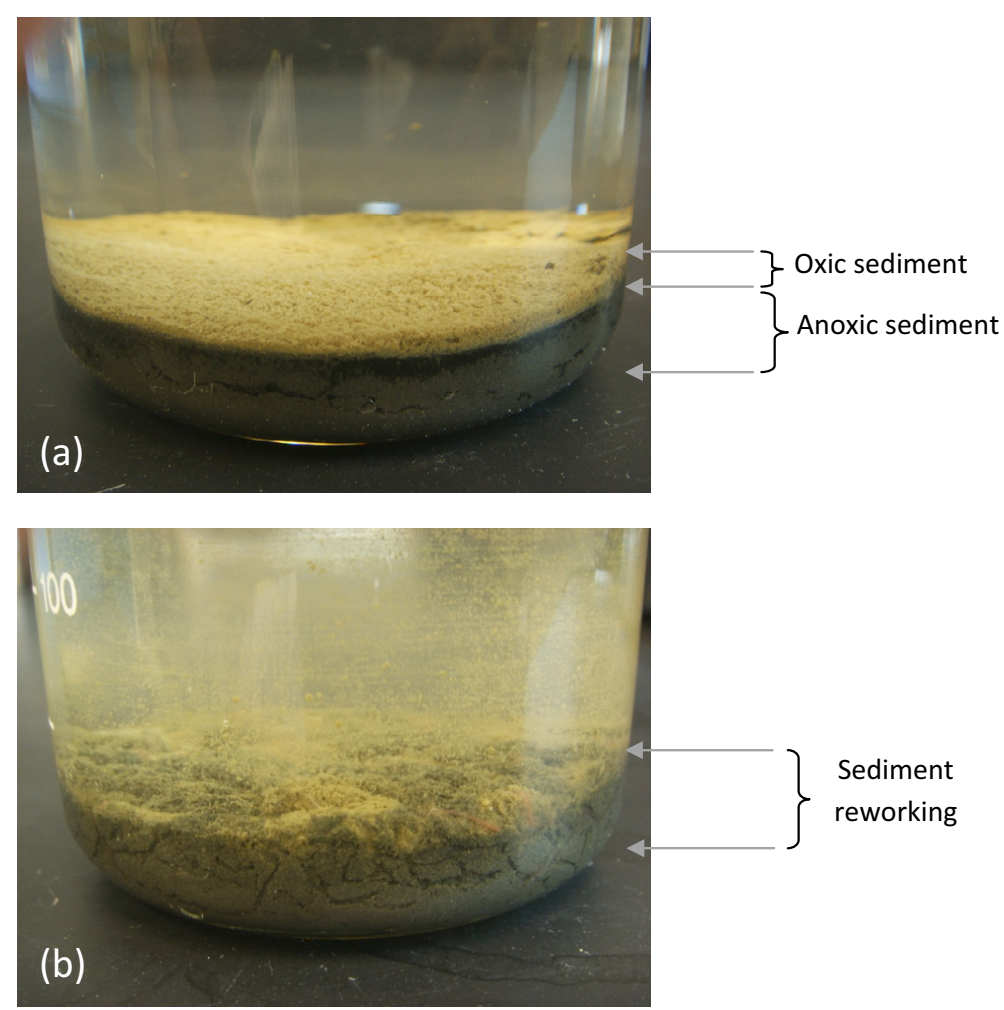

\section{Figure 4}

(a) and (b) show the aspect of the sediment of the control and the experimental line with no worms and higher abundances of worms, respectively, after ten days of experiment.

within the sediment, bioturbation may inhibit to a notable extent the translocation of soluble phosphorus to overlaying water in fish farm settling ponds.

\section{> POTENTIAL CONTRIBUTION OF BIOTURBATION IN SETTLING PONDS TO REDUCE PHOSPHORUS DISCHARGED BY FISH FARMING ACTIVITY}

Under the experimental conditions here tested, tubificid worms inhabiting the sedimentation pond of a fish farm facility might contribute to reduce the phosphorus discharge (at least in terms of soluble phosphorus) (see Sect. 3.3). In order to quantify the extent of this contribution some assumptions must be made. Accordingly, we assume that (1) The total amount of phosphorus deposited to the bottom of a trout production can be conveyed to a settling pond and this is $3.545 \mathrm{~kg} \mathrm{P} \cdot$ tone $^{-1}$ of fish produced (Puigagut et al., 2011); (2) the pond have an homogeneous tubificids abundance of 22000 individuals. $\mathrm{m}^{-2}$; (3) Total phosphorus concentration of the sediment is that of $3.1 \mathrm{mg}$ of $\mathrm{P} \cdot \mathrm{g}^{-1}$ dry matter (Table I); (4) The content of dry mater is that of ca. $36 \%$ (Table I); (5) Tubificid worms might avoid phosphorus translocation of ca. $45 \mathrm{mg} \mathrm{PO}-3 \cdot \mathrm{kg}^{-1}$ TS (cumulative translocation of phosphorus from the control line minus the cumulative translocation of the experimental condition of 22000 individuals $\cdot \mathrm{m}^{-2}$ ) (Figure 6); (6) Annual fish production is that of 25 tonnes; (7) we assume that bioturbation effect on phosphorus translocation is limited to the first $2 \mathrm{~cm}$ of sediment layer since in field measurements this was the actual tubificids distribution. Therefore, by taking into account all of the previous assumptions we might theoretically calculate (see Appendix A for details on the calculation) that tubificid worms inhabiting the sedimentation pond might reduce the phosphorus discharge (in terms of soluble phosphorus) in ca. $5 \mathrm{~g}$ of P.ton ${ }^{1}$ of fish produced (calculation 1) or ca. $0.13 \mathrm{~kg}$ of phosphorus per annual production (calculation 2). Therefore, soluble phosphorus retention by bioturbation in settling ponds is between 10 to 25 times 
higher than that described when applying sludge drying beds (Puigagut et al., 2011). This result show that settling ponds subjected to bioturbation under the conditions here considered may contribute to reduce soluble phosphorus leaching. In spite of the limitations considered in the previous theoretical approach, authors believe that a reasonable scenario is defined to show the extent of bioturbation contribution to phosphorus retention within the domain of fish farming.

\section{CONCLUSIONS}

Nitrate and phosphate dynamics across water-sediment interface were significantly affected by tubificid abundances of 22000 individuals $\mathrm{m}^{-2}$. Tubificid abundances of 550 individuals $\cdot \mathrm{m}^{-2}$ did not affect the translocation of nutrients across water-sediment interface.

Nitrate uptake by sediments having tubificid abundances of 22000 individuals $\cdot \mathrm{m}^{-2}$ was significantly lower (55\% lower) when compared to control conditions (no worms present) and phosphate released by the sediment was ca. $90 \%$ higher for the control conditions (no worms present).

Results here reported on the retention of phosphorus subjected to high conditions of bioturbation (22000 individuals $\left.\cdot \mathrm{m}^{2}\right)$ allowed us to estimate that settling ponds of fish farming facilities may contribute to decrease phosphorus discharge (in terms of soluble phosphorus) in ca. $5 \mathrm{~g}$ of P.ton ${ }^{-1}$ of fish produced.

\section{ACKNOWLEDGEMENTS}

This project was funded by the Natural Sciences and Research Council of Canada (CRSNG), "La Société de recherche et de développement en aquaculture continentale" du Québec (SORDAC) and Multiserv. Authors also want to thank the collaboration of Pisculture Gilbert and Denis Bouchard for the technical assistance. We also want to thank to Marie Laure de Boutray and Marta Balaux for their help during experimental deployment.

\section{SUPPLEMENTARY MATERIAL}

Supplementary material. Calculations of the amount of soluble phosphorus that could be saved up by the effect of bioturbation within a settling pond (per ton of fish produced Calculation1 and per year - Calculation 2).

Calculation 1

$$
\frac{4.5 \times 10^{-3} \mathrm{~g} \cdot \mathrm{PO}_{4}^{-3}}{\mathrm{~kg} \cdot \mathrm{TS}} \frac{1 \mathrm{~kg} \cdot \mathrm{TS}}{3.1 \times 10^{-3} \mathrm{~kg} \cdot \mathrm{TP}} \frac{3.545 \mathrm{~kg} \cdot \mathrm{P}}{\mathrm{Ton} \cdot \mathrm{fish}}=\frac{5.14 \mathrm{~g} \cdot \mathrm{PO}_{4}^{-3}}{\text { Ton } \cdot \text { fish }} .
$$

Calculation 2

$$
\frac{5.14 \mathrm{~g} \cdot \mathrm{PO}_{4}^{-3}}{\text { Ton } \cdot \text { fish }} \frac{25 \cdot \text { tons } \cdot \text { fish }}{\text { year }} \frac{1 \mathrm{~kg}}{10^{3} \mathrm{~g}}=\frac{0.128 \mathrm{~kg} \cdot \mathrm{PO}_{4}^{-3}}{\text { year }} .
$$

Calculation 3

$$
\frac{4.8 \frac{\mathrm{g} \cdot \mathrm{Fe}}{\mathrm{g} \cdot \mathrm{TS}}}{3.1 \frac{\mathrm{g} \cdot \mathrm{P}}{\mathrm{g} \cdot \mathrm{TS}}} \frac{55.8 \cdot \mathrm{mols}}{1 \mathrm{~g} \cdot \mathrm{Fe}} \frac{1 \mathrm{~g} \cdot \mathrm{P}}{30.9 \cdot \mathrm{mols}}=2.8
$$




\section{REFERENCES}

Adámek Z. and Maršálek B., 2013. Bioturbation of sediments by benthic macroinvertebrates and fish and its implication for pond ecosystems: a review. Aquaculture international. DOI: 10.1007/s10499-012-9527-3.

Aller R.C., 1994. Boioturbation and remineralization of sedimentary organic matter: effects of redox oscillation. Chem. Geology, 114, 331-345.

Andersen $F \varnothing$ and Jensen H.S., 1991. The influence of chironomids on decomposition of organic matter and nutrient Exchange in a lake sediment. Verhandlungen der internationale Vereinigung für Theoretische und Angewandte Limnologie, 24, 3051-3055.

Andersson G., Graneli W. and Stenson J., 1988. The influence of animals on phosphorus cycling in lake ecosystems. Hydrobiologia, 170, 267-284.

Apha-Awwa-Wpcf., 2001. Standard Methods for the Examination of Water and Wastewater, 20th ed. American Public Health Association, Washington, DC.

Banta G.T., Holmer M., Jensen M.J. and Kristensen E., 1999. The effect of two polychaete worms, Nereis diversicolor and Arenicola marina, on decomposition in an organic-poor and an organicenriched marine sediment. Aquat. Microb. Ecol., 19, 189-204.

Bergheim A. and Brinker A., 2003. Effluent treatment for flow through systems and European Environmental Regulations. Aquacult. Eng., 27, 61-77.

Boaventura R., Pedro A.M., Coimbra J. and Lencastre E., 1997. Trout farm effluents: characterization and impact on the receiving streams. Environ. Pollut., 95, 379-387.

Chatarpaul L., Robinson J.B. and Kaushik N.K., 1980. Effects of tubificid worms on denitrification and nitrification in stream sediment. Can. J. Fish. aquat. Sci., 37, 656-663.

Cripps S.J. and Bergheim A., 2000. Solids management and removal for intensive land-based aquaculture production systems. Aquacult. Eng., 22, 33-56.

Davis R.B., 1974. Tubificids alter profiles of redox potential and pH in profundal lake sediment. Limnol. Oceanogr., 19, 342-346.

Davis R.B., Thurlow D.L. and Brewster F.E., 1975. Effects of burrowing tubificid worms on the exchange of phosphorus between lake sediment and overlying water. Verh. int. Verein Limnol., 19, 382-394.

Delgado O., Ruiz J., Pérez M., Romero J. and Ballesteros E., 1999. Effects of fish farming on seagrass (Posidonia oceanica) in a Mediterranean bay: seagrass decline after organic loading cessation. Oceanologica Acta, 22, 109-117.

Devine J.A. and Vanni M.J. 2002. Spatial and seasonal variation in nutrient excretion by benthic invertebrates in a eutrophic reservoir. Fresh Water Biol., 47, 1107-1121.

François F., Gerino M., Stora G., Durbec J.P. and Poggiale J.C., 2002. A functional approach to sediment reworking by gallery forming macrobenthic organisms: modelling and application with the polychaete Nereis diversicolor. Marine Ecology Progress Series, 229, 127-136.

Fukuhara H. and Sakamoto M., 1987. Enhancement of inorganic nitrogen and phosphate release from lake sediment by tubificid worms and chironomid larvae. Oikos, 48, 312-320.

Gerino M., Stora G., François-Carcaillet F., Gilbert F., Poggiale J.C. and Mermillod-Blondin F., 2003. Macro-invertebrate functional groups in freshwater and marine sediments: a common mechanistic classification. Vie et Milieu, 53, 221-231.

Gilbert F., Bonin P. and Stora G., 1995. Effect of bioturbation on denitrification in a marine sediment from the West Mediterranean littoral. Hidrobiologia, 304, 49-58.

Heilskov A.C.H. and Holmer M., 2001. Effects of benthic fauna on organic matter mineralization in fishfarm sediments: importance of size and abundance. ICES J. Mar. Sci., 58, 427-434.

Krantzberg G., 1985. The influence of bioturbation on physical, chemical and biological parameters in aquatic environments: a review. Environ Pollut. (series A) 39, 99-122.

Lagauzère S., Pischedda L. Cuny P., Gilbert F., Stora G. and Bonzom J.M., 2009. Influence of Chironomus riparius (Diptera, Chironomidae) and Tubifex tubifex (Annelida, Oligochaeta) on oxygen uptake by sediments. Consequences of uranium contamination. Environ. Pollut., 157, 1234-1242.

Lefrançois P., Puigagut J., Chazarenc F. and Comeau Y., 2010. Minimizing Phosphorus Discharge from Aquaculture Earth Ponds by a Novel Sediment Retention System. Aquacult. Eng., 43, 94-100. 
Lewandowski J. and Hupfer M., 2005. Effect of macrozoobenthos on two-dimensional small-scale heterogeneity of pore water phosphorus concentrations in lake sediments: A laboratory study. Limnol. Oceanogr, 50, 1106-1118.

Matisoff G., Fisher J.B. and Matis S., 1985. Effects of benthic macroinvertebrates on the exchange of solutes between sediments and freshwater. Hydrobiologia, 122, 19-33.

Mermillod-Blondin F. and Rosenberg R., 2006. Ecosystem engineering: the impact of bioturbation on biogeochemical processes in marine and freshwater benthic habitats. Aquat Sci., 68, 434-442.

Mermillod-Blondin F., Nogaro G., Datry T., Malard F. and Gibert J., 2005. Do tubificid worms influence the fate of organic matter and pollutants in stormwater sediments? Environ. Pollut. 134, 57-69.

Mortimer R., Davey J.T., Krom M.D., Watson P.G., Frichers P.E. and Clifton R.J., 1999. The effect of macrofauna on porewater profiles and nutrient fluxes in the intertidal zone of the Humber Estuary. Estuarine, Coastal and Shelf Science, 48, 683-699.

Navel S., Mermillod-Blondin F., Montuelle B., Chauvet E. and Marmonier P., 2011. Sedimentary context controls the influence of ecosystem engineering by bioturbators on microbial processes in river sediments. Oikoos. DOI: 10.1111/j.1600-0706.2011.19742.x.

Nogaro G. and Mermillod-Blondin F., 2009. Stormwater Sediment and Bioturbation Influences on Hydraulic Functioning, Biogeochemical Processes, and Pollutant Dynamics in Laboratory Infiltration Systems. Environ. Sci. Technol., 43, 3632-3638.

Nogaro G., Mermillod-Blondin F., Valett M.H., François F.C., Gaudet J.P., Lafont M. and Gibert J., 2009. Ecosystem engineering at the sediment-water interface: bioturbation and consumer-substrate interaction. Oecologia, 161, 125-138.

Phillips G., Jackson R., Bennett C. and Chilvers A., 1994. The importance of sediment phosphorus release in the restoration of very shallow lakes (The Norfolk Broads, England) and implications for biomanipulation. Hydrobiologia, 275-276, 445-456.

Puigagut J., Angles H., Chazarenc F. and Comeau Y., 2011. Decreasing phosphorus discharge in fish farm ponds by treating the sludge generated with sludge drying beds. Aquaculture, 38, 7-14.

Reddy K.R., Kadlec R.H., Flaig E. and Gale P.M., 1999. Phosphorus Retention in Streams and Wetlands: A Review. Crit. Rev. Env. Sci. Tec., 29, 83-146.

Reible D.D. Popov V., Valsaraj K.T., Thibodeaux L.J., Lin F., Dikshit M., Todaro M.A. and Fleeger J.W. 1996. Contaminant fluxes from sediment due to tubificid oligochaete bioturbation, Water Res., 30 , 704-714.

Svensson J.M., Enrich-Prast A. and Leonardson L., 2001. Nitrification and denitrification in eutrophic lake sediment bioturbated by oligochaetes. Aquat. Microb. Ecol., 23, 177-186.

True B., Johnson W. and Chen S., 2004. Reducing phosphorus discharge from flow-through aquaculture I: facility and effluent characterization. Aquacult. Eng., 32, 129-144.

Van de Bund W.J., Goedkoop W. and Johnson R.K., 1994. Effects of deposit-feeder activity on bacterial production and abundace in profundal lake sediment. J. North Am. Benthol. Soc., 13, 532-539.

Zhang L., Gu X., Fan C., Shang J., Shen Q., Wang Z. and Shen J., 2010. Impact of different benthic animals on phosphorus dynamics across the sediment-water interface. J. Environ. Sci., 22, 1674-1682. 